\title{
Research on the Scientific Evolution of the Flavonoid Agathisflavone
}

\author{
Vanessa Cristina Meira de Amorim; Markley Silva Oliveira Júnior; Eduardo Muniz Santana Bastos; Victor Diogenes Amaral
} da Silva; Silvia Lima Costa

Laboratory of Neurochemistry and Cell Biology, Department of Biochemistry and Biophysics, Institute of Health Sciences, Federal University of Bahia.

Received August 7, 2018; Revised, September 20, 2018; Accepted, October 14, 2018; Published, October 14, 2018

\begin{abstract}
Purpose: Flavonoids are a group of secondary metabolites of the polyphenols class present in several plant species. Among them, the biflavonoid agathisflavone is of interest since it bears several biological effects that include: antiviral, antitumoral, antiprotozoal and neurogenic actions. In this sense, this study aims to use the important tool of scientific prospecting to assess the level of research development concerning the flavonoid agathisflavone. Methods: The experimental design was carried out through strategic reach with keywords on the PubMed (National Center for Biotechnology Information - NCBI) and Science Direct platforms. The articles were compiled and exported to Microsoft Office Excel 2007, where they were analyzed, stored and distributed in charts organized as to different countries, year of publication of scientific articles and journals RESULTS: The prospective research resulted in the identification of 81 scientific productions, published in several journals, submitted by different countries, in several areas of medical domain and in different years of publication over the last 50 years (1965 - 2018). It was also possible to investigate the advances in the study of agathisflavone for the development of new therapeutics. Conclusion: Although agathisflavone has been known in the literature since at least 1969, only 23 of the eligible articles found evaluated its possible therapeutic effects. The demonstrated biological activities of agathisflavone range from antiprotozoal to neurogenesis and neuroprotection, however, the molecule needs to be better studied at the in vivo and human level.
\end{abstract}

\section{INTRODUCTION}

Flavonoids account for a large group of secondary metabolites of plant origin of the polyphenol class. They are found in different plant groups and may be present in several parts of plants, such as fruits, vegetables, seeds, bark, roots, stems and flowers (1). These compounds are formed by the combination of derivatives synthesized from phenylalanine (shikimic acid metabolic pathway) and acetic acid. The basic structure of flavonoids is composed of fifteen atoms of carbon arranged in structures with two phenolic rings $\mathrm{A}$ and $\mathrm{B}$ and a heterocyclic pyran or pyrone ring $\mathrm{C}$ with a carbonyl group in position C-4 (2).

Several biological activities are attributed to flavonoids, such as antitumor (3), antioxidant (4), antiviral (5), and anti-inflammatory properties (6), among others, which give this group of compounds notable pharmacological significance. What makes them even more attractive is that flavonoids are integrated and abundant in diets rich in fruits and vegetables and that they have little or no adverse effects (7).
A specific class of flavonoids that has drawn the interest from scientific researchers is the class of biflavonoids, compounds composed of a combination of flavonoid dimers connected by C-C or C-O-C bonds (8). This class of flavonoids has several therapeutic effects, sometimes having higher pharmacological efficiency than their respective monomers. Thapa et al. (2011) (7) reported that the biflavonoid taiwaniaflavone was more efficient than its monomer, apigenin, in inhibiting $\mathrm{A} \beta$ toxicity and decreasing fibrillogenesis in in vitro models of Alzheimer's Disease (AD). In another study, morelloflavone showed a more potent antioxidant activity than its monomer, quercetin (9). Agathisflavone (Fig. 1), a flavonoid produced by oxidative coupling of two apigenins (10), has been investigated for its pharmacological potential showing promising in vitro effects, such as antibiotic (11), antiviral (12,13), antiprotozoal (14) and antitumor $(15,16)$.

Corresponding Author: Professor Silvia Lima Costa: Instituto de Ciências da Saúde Av. Reitor Miguel Calmon s/no Vale do Canela, Salvador-Bahia, 40110-902, Brazil, E-mail address: costasl@ufba.br 
Agathisflavone has also shown positive effects in the induction of neurogenesis and neuronal differentiation $(17,18)$, as well as neuroprotection against glutamate-induced neurotoxicity (18).

The present study presents an overview of the biflavonoid agathisflavone in the international scenario, aiming to evaluate the presence of this flavonoid in the scientific literature, as well as to identify possible uses for a therapeutic approach.

\section{METHODS}

For this research, an exploratory scientific prospection was carried taking into consideration all publications, with the objective of identifying investigations about agathisflavona in the scientific literature. We used PubMed, the database of the National Library of Medicine of the United States of America, developed by the National Center for Biotechnology Information (NCB) and maintained by the National Library of Medicine, the free version of the Medline database, available on http://www.nlm.nih.gov/citingmedicine and Science Direct, the Elsevier scientific literature platform belonging to the RELX group, available on http://www.sciencedirect.com.

PubMed comprises more than 26 million citations from Medline's biomedical literature, science journals and several online books. Science Direct includes more than 12 million citations in several fields of science, more than 3,500 scientific journals and more than 34,000 electronic books.

The research itself includes scientific articles from a number of journals. Data collection was performed in February 2018, using the keywords "agathisflavone" and "6,8-biapigenin" in the title, abstract and key words.

The articles were compiled and exported to Microsoft Office Excel 2007, where they were analyzed, stored and distributed in charts organized as to different countries, year of publication of scientific articles and journals (Fig. 1).

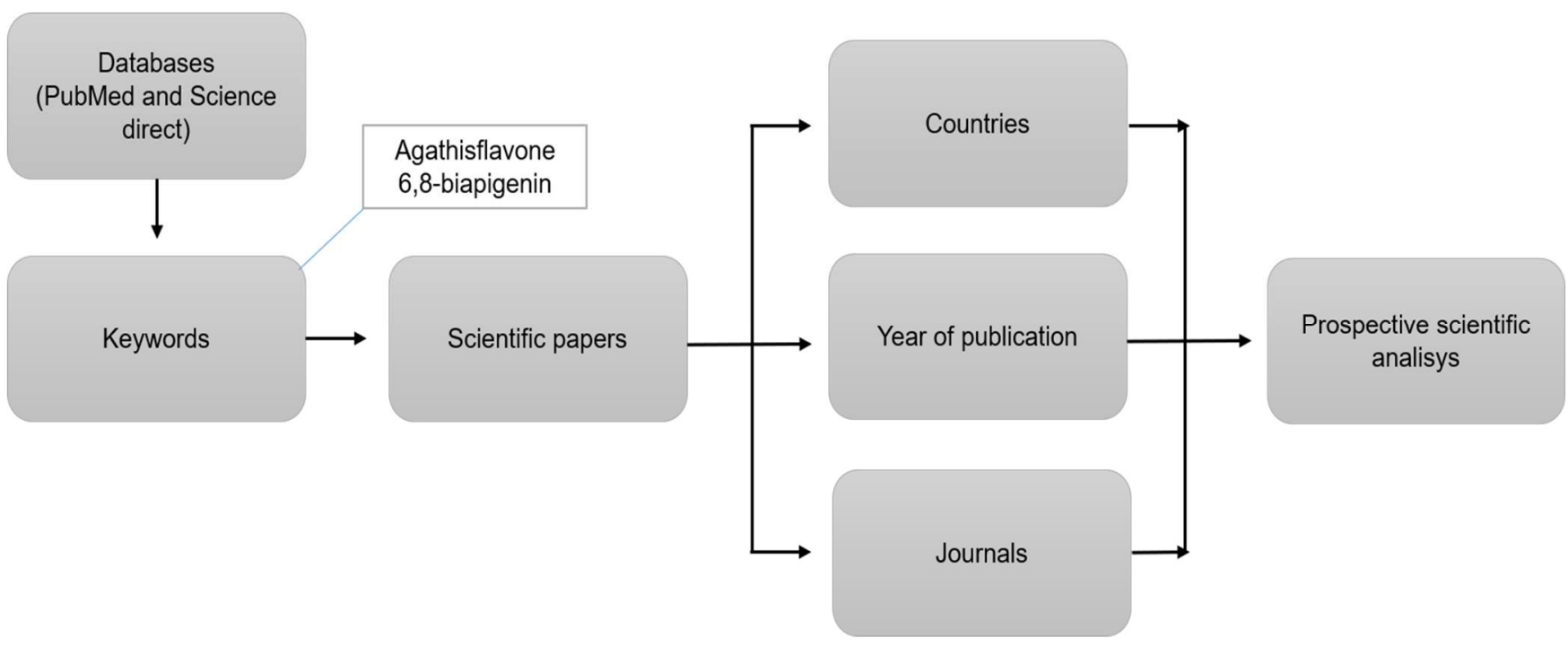

Figure 1. Experimental design of the prospective scientific study of agathisflavone.

\section{RESULTS AND DISCUSSION}

\section{Prospective analysis}

We found a total of 81 scientific publications between 1969 and 2018, with 16 articles referred on the Pubmed platform, 55 on the Science Direct platform and 10 appearing on both platforms, as shown in figure 2. In the period from 2012 to 2018, there was an increase in the number of scientific productions mentioning agathisflavone (Fig. 3).
The journal with the highest number of publications mentioning agathisflavone is Phytochemistry, with 19 publications, followed by Journal of Ethnopharmacology and Tetrahedron Letters, with 9 and 6 publications, respectively (Fig. 4). As for the countries responsible for the publications, Brazil was the country with the largest number, with 16 publications, followed by China and Germany, with 11 publications each (Fig. 5). 
An important aspect to note in this prospection is that publications frequently found on the Pubmed database were not available on Science Direct and vice versa. Sixteen of the papers found on Pubmed appear only on this database, and so do 55 of the papers found on Science Direct. Only 10 of the 81 publications were found on both databases. It demonstrates the importance of collecting data for scientific research using more than one source, because publications of a particular subject do not always appear universally on all databases.

\section{Background of extraction and identification of agathisflavone}

The literature reports that the flavonoid agathisflavone is present in plants of different genus, in different parts of plants, and can be extracted by several methods, being found in extracts of various solvents. The first article found in this study only mentions agathisflavone as one of the flavonoids that can be identified in the plant Searsia succedanea (Rhus succedanea) (19).

Chexal et al. (1970) (20) reported that thin-layer chromatography on silica gel, using benzenepyridine formic acid as a solvent, allowed the easy identification and separation of 28 distinct biflavonoids, among them agathisflavone. Yuh-Meei and Fa-Ching (1974) (21) used thin-layer chromatography on polyamide and methanol solvent, followed by nuclear magnetic resonance
(NMR) spectroscopy, to isolate and identify agathisflavone from Searsia succedanea (Rhus succedanea). The authors reported that this method allowed the extraction of larger amounts of flavonoid than did the methods used in articles published in the literature until then.

Ilyas et al. (1978) (22) reported the presence of agathisflavone in a phenolic extract of leaves of Araucaria excelsa, while Wannan et al. (1985 and 1988) $(23,24)$ reported the same in the ethanolic extract of Blepharocarya depauperata, Amphipterygium schiede and Orthopterygium hemsley. Anand et al. (1992) (25) purified the flavonoid from the methanolic extract of the Canarium manii nuts. Mendes et al. (2000) (26) and Bahia et al. (2005) (10) reported the presence of agathisflavone in the chloroform extract of leaves of Poincianella (Caesalpinea) pyramidalis. The first report on the extraction of agathisflavone, from a plant of the genus Ouratea, Ouratea sulcata, was made by Pegnyemb et al. (2005) (27), from the methanolic extract of the leaves. Svenningsen et al. (2006) (28) extracted agathisflavone from the ethanolic extract of the leaves of Rhus pyroides by means of the high-performance liquid chromatography (HPLC) technique. Bermudez et al. (2012) (29) used high-speed countercurrent chromatography to extract agathisflavone from the leaves and stems of Ouratea polyantha Engl. (Ocnhaceae).

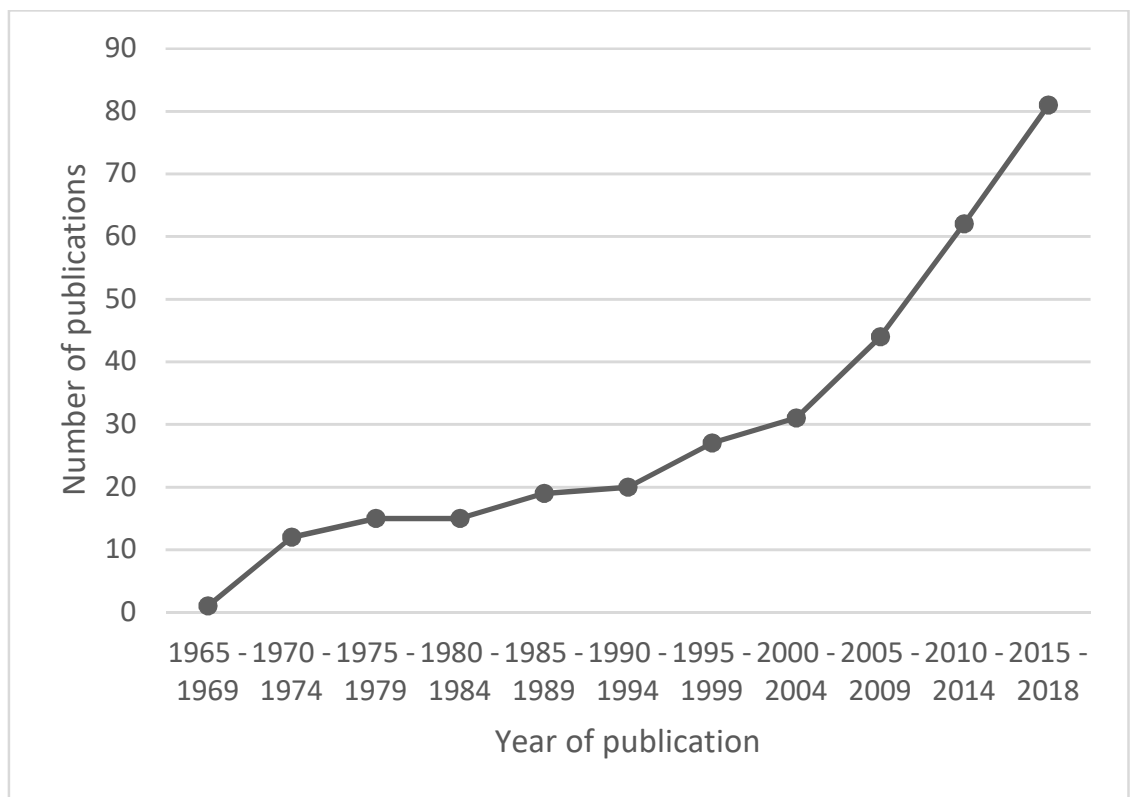

Figure 2. Cumulative annual evolution of scientific publications mentioning the flavonoid agathisflavone on the PubMed and Science Direct databases. 


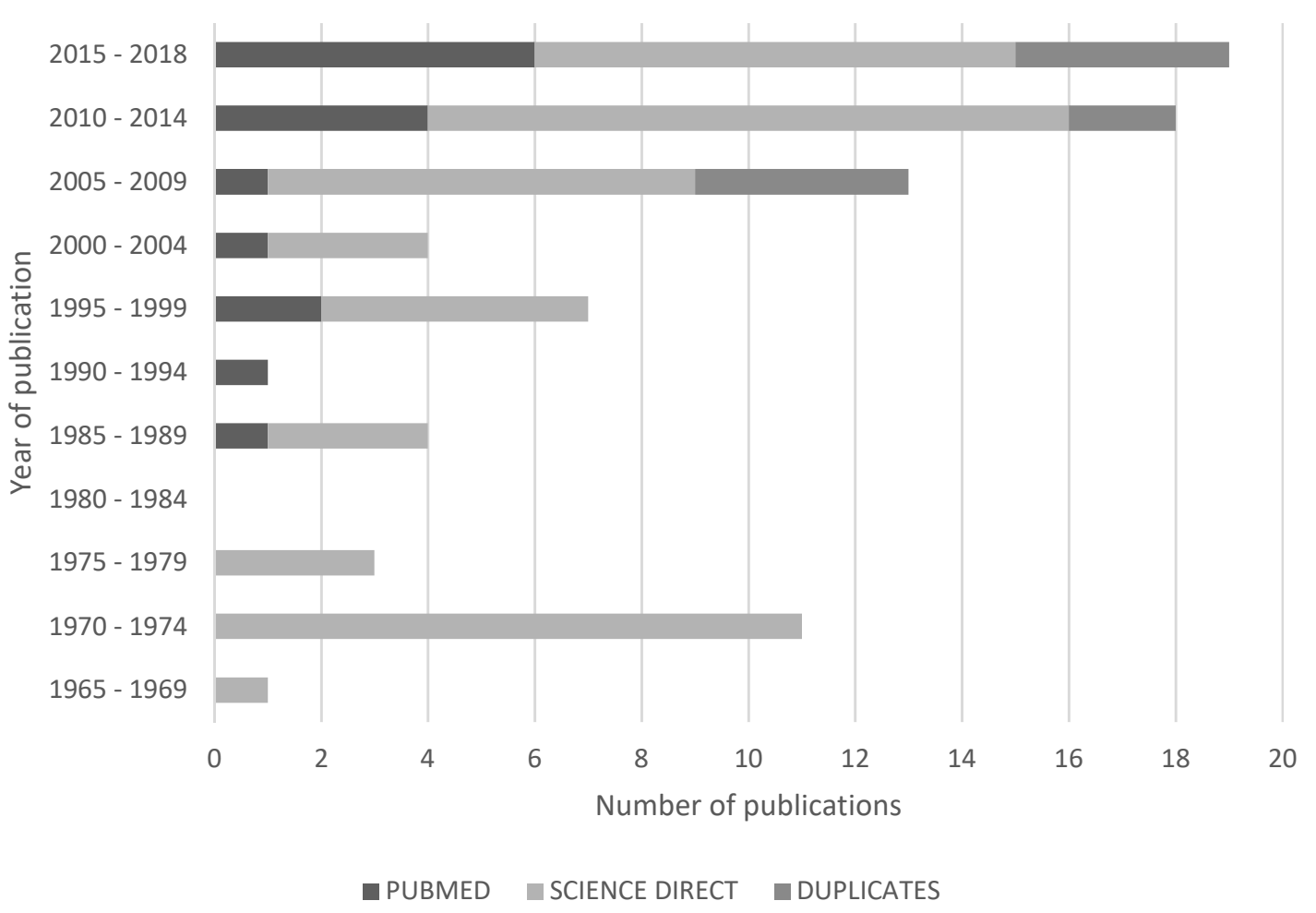

Figure 3. Annual evolution of scientific publications mentioning the flavonoid agathisflavone on the PubMed and Science Direct databases.

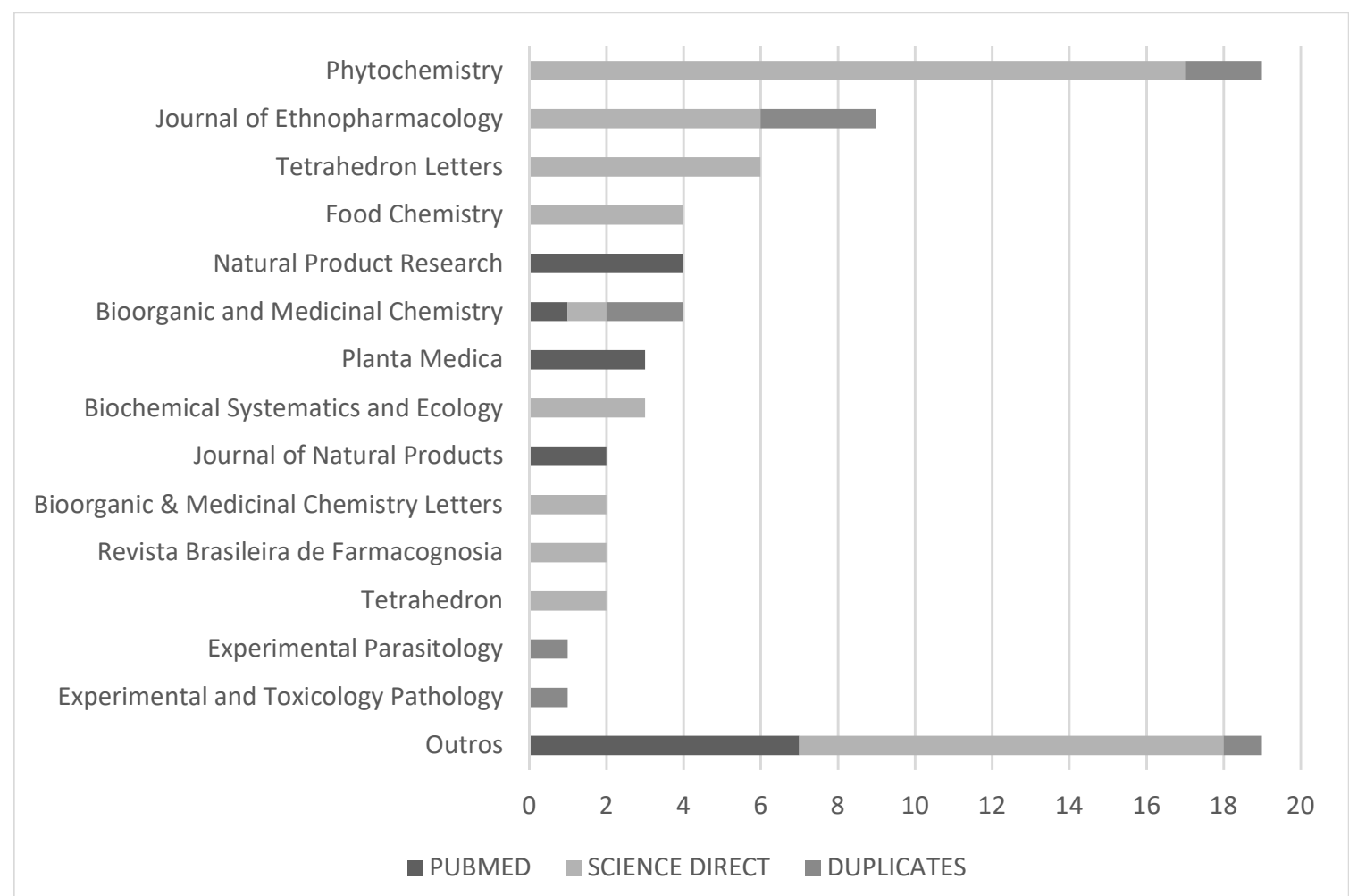

Figure 4. Number of scientific publications mentioning the flavonoid agathisflavone by journal on the PubMed and Science Direct databases. 


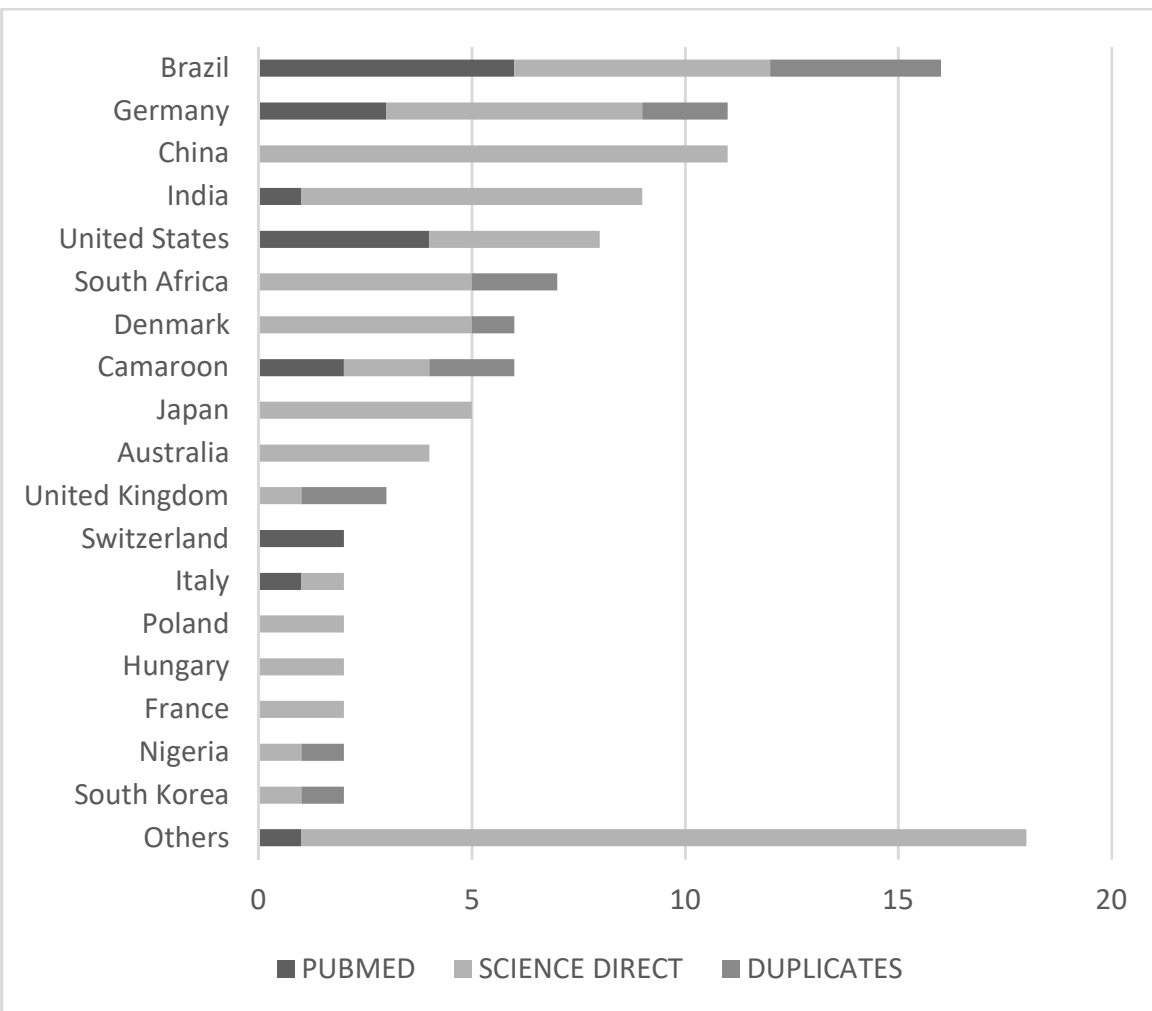

Figure 5. Number of contributions from each country on papers mentioning the flavonoid agathisflavone on the PubMed and Science Direct databases.

Njock et al. (2012) (30) used NASCA-HMBC, a new type of nuclear magnetic resonance (NMR) with high resolution, to facilitate the identification of agathisflavone in the extract of Ouratea gilgiana leaves and stem. Konan et al. (2012) (15) reported the presence of agathisflavone in the ethanolic extract of the leaves of the cashew tree (Anacardium occidentale L.). The first report on the presence of agathisflavone in Schinus terebinthifolius Raddi was made by Feuereisen et al. (2014) (31), who identified the flavonoid in the phenolic extract of the exocarp. Ochna schweinfurthiana, a common plant adopted in African traditional medicine, also has this flavonoid in its methanolic extract, as demonstrated by Ndongo et al. (2015) (32). Covington et al. (2016) (33) described for the first time the absolute configuration of the agathisflavone molecule through methods of chiroptical spectroscopy.

\section{Biological effects}

\section{Viability of tumor cells}

The first mention found of in vitro tests for possible therapeutic effects of agathisflavone was in 1989 by Lin et al. (1989) (34) who carried out a screening of the cytotoxicity of biflavonoids found in the Searsia succedanea (Rhus succedanea) plant, among them agathisflavone, which did not demonstrate significant cytotoxicity against $\mathrm{KB}$ tumor cells (squamous cell carcinoma of the mouth) in the test performed.

Reports on the anticancer potential of agathisflavone were first made by Grynberg et al. in 2002 (35). The authors tested in vitro the potential of agathisflavone in the inhibition of topoisomerase (enzyme target of several drugs for the treatment of cancer) in Ehrlich carcinoma cells, presenting a significant effect at the concentration of $200 \mu \mathrm{M}$. The biflavonoid also demonstrated the dose-dependent ability to inhibit the growth of carcinoma cells, with EC50 of $24 \pm 1.4 \mu \mathrm{M}$. In an article published in 2012, Konan et al. (15) observed the effects of agathisflavone extracted from cashew leaves (Anacardium occidentale L.) on tumor lines. Flow cytometry and $[3 \mathrm{H}]$-Timidine incorporation assay were used to evaluate the effect of the flavonoid, which demonstrated high ability to prevent proliferation of Jurkat cells ( $\mathrm{T}$ lymphocyte-derived cell line) with an EC50 of $2.4 \mathrm{~g} / \mathrm{mL}(4.45 \mu \mathrm{M})$.

Agathisflavone also showed moderate cytotoxic effect in HL60 cells (promyelocytic acute leukemia), 
Burkitt lymphoma and Hep-2 laryngeal carcinoma cells. Ndongo et al. (2015) (32) evaluated the cytotoxicity of agathisflavone, extracted from Ochna schweinfurthiana, in HeLa cells (line derived from cervical adenocarcinoma). In this study, agathisflavone demonstrated cytotoxic activity, with an EC50 of $10 \mu \mathrm{M}$. Marzouk (2016) (36) reported that agathisflavone, extracted from the plant Erucaria hispanica (L.), also demonstrated cytotoxicity against HeLa cells, with an EC 50 of $20.3 \mu \mathrm{g} / \mathrm{mL}$. Taiwo et al. (2017) (16) evaluated the cytotoxic effects of four flavonoids extracted from the plant Anacardium occidentale L. on HeLa cells, among them agathisflavone. In addition, the authors developed computational models to evaluate the binding ability of the four compounds to seven molecular targets (MAPK8, MAPK10, MAP3K12, MAPK3, MAPK1, MAPK7 and VEGF) that are involved in the growth, proliferation, maintenance and metastasis of tumor cells. Although this model suggests that agathisflavone, among the four flavonoids tested, has the strongest binding to these molecular targets, it was shown to be only the second most cytotoxic substance, with an EC50 of $84.7 \mu \mathrm{M}$, compared to the EC50 of $36.2 \mu \mathrm{M}$ of the most active compound (zoapatanolide A). The authors suggest that one of the reasons for so is the physicochemical properties of the flavonoid agathisflavone, which could render it less able to penetrate biological membranes and limit the access of the compound to the receptor sites.

\section{Antiviral activity}

In 1997, Lin et al. (12) demonstrated for the first time the antiviral activity in vitro of agathisflavone. At a concentration of $100 \mu \mathrm{M}$, this flavonoid was shown to be able to inhibit the activity of the HIV-1 reverse transcriptase enzyme. It also showed significant ability to inhibit HIV virus multiplication in human lymphocytes. In 1999, Lin et al. (37) reported that agathisflavone showed significant anti-viral activity against Influenza $\mathrm{H} 1 \mathrm{~N} 1$ and Influenza $\mathrm{B}$ virus, at concentrations of $6 \mu \mathrm{g} / \mathrm{mL}$ and $3.2 \mu \mathrm{g} / \mathrm{mL}$, respectively.

Zembower et al. (1998) (38) tested the antiviral properties of agathisflavone isolated from the plant Searsia succedanea (Rhus succedanea) against the hepatitis B virus but did not obtain positive results in the EC50 tests performed. In the work published by De Sousa et al. (2015a) (13), agathisflavone was shown to be a non-competitive inhibitor of dengue virus serotype 2 NS2B-NS3 protease, with Ki values of $11 \mu \mathrm{M}$. This protease is essential for the replication process of the virus and has been studied as a promising molecular target for anti-dengue virus medications.

\section{Antibiotic activity}

The first test to investigate the antibiotic potential of agathisflavone was by Lin et al. (2001) (39). Several biflavonoids were evaluated for their inhibitory activity against Mycobacterium tuberculosis (tuberculosis agent) in vitro, but agathisflavone had no effect on the concentration used, $12.5 \mu \mathrm{g} / \mathrm{mL}$. Ngo Mbing et al. (2006) (40) tested agathisflavone from the plant Ouratea nigroviolacea in vitro using the Mueller-Hinton agar diffusion assay to evaluate antimicrobial activity against Enterococcus sp., E. hirae (ATCC 9790), Staphylococcus aureus (ATCC 25923), Staphylococcus saprophyticus, Acinetobacter baumanii and Pseudomonas aeruginosa (ATCC 27853), but none of the bacteria was susceptible to the flavonoid. Similarly, Da Silva et al. (2017) (41) tested the minimal inhibitory concentration of agathisflavone extracted from the leaves and fruits of the plant Schinus terebinthifolius against $E$. coli and found no inhibitory activity. The only finding reported in the literature demonstrating the positive effect of agathisflavone as an antibiotic was published by Ajileye et al. (2015), where agathisflavone extracted from Anacardium occidentale showed moderate inhibitory activity with a minimum inhibitory concentration of $1.0 \mathrm{mg} /$ $\mathrm{mL}$ against most of the pathogens tested (B. subtilis, $C$. sporogenes, $E$. coli, $K$. pneumonia, $P$. fluorescences, $P$. aeruginosa and $S$. aureus). These authors were also the only ones in the period evaluating the antioxidant capacity of agathisflavone using the DPPH free radical scavenging assay, the total antioxidant capacity determination test and the antioxidant determination power reduction test. Agathisflavone did not demonstrate significant antioxidant capacity in any of the tests performed.

\section{Activity on the nervous system}

In an article published in 2006, Svenningsen et al. (28) reported for the first time the affinity of agathisflavone for the benzodiazepine/GABAA receptor, an important molecular target for antiepileptic medications. Agathisflavone extracted from the plants Searsia dentata (Rhus dentata), Searsia penteri (Rhus penteri) and Searsia pyroides (Rhus pyroides) underwent a [3H] -Flumazenil binding assay to evaluate the affinity to $\mathrm{GABA}_{\mathrm{A}}$ 
receptor. Agathisflavone showed significant affinity for the receptor in this assay, with a $\mathrm{Ki}$ value of 28 $\mathrm{nM}$, whereas apigenin, also tested, showed much lower activity with $\mathrm{Ki}$ of only $7.6 \mu \mathrm{M}$. In this case, the biflavonoid was shown to be a more active compound than its monomer. Shrestha et al. (2012) (42) reported that agathisflavone extracted from Rhus parviflora, using the same [3H] -Flumazenil binding assay, showed $\mathrm{Ki}$ of $0.091 \mu \mathrm{M}$. However, Pedersen et al. (2008) (43) tested the antiepileptic effects of agathisflavone (in concentrations from 0.01 to $100 \mu \mathrm{M}$ ) on slices of cerebral cortex of mice submitted to spontaneous epileptic discharges and did not obtain positive results.

Paulsen et al. (2011) (17) reported that agathisflavone extracted from the plant Poincianella pyramidalis (Tul.) (Caesalpinia pyramidalis), when used at the concentration of $10 \mu \mathrm{M}$ in combination with retinoic acid (RA) at $60 \mu \mathrm{M}$ in murine embryonic stem cells and induced pluripotent stem cells, enhanced AR-induced neuronal differentiation by two-fold or more in both cell types. In addition, agathisflavone increased the expression of RAR $\alpha$ and RAR $\beta$ receptors in murine embryonic stem cells. In another study, Dos Santos Souza et al. (2018) (18) tested the effects of agathisflavone from this same plant on primary glia and neuron co-cultures from the cerebral cortex of neonatal rats. Compared to the control, treatment with agathisflavone at $10 \mu \mathrm{M}$ increased the number of mature neurons and neural progenitors, without affecting the number of astrocytes and microglia. These effects were suppressed by estrogen receptor antagonists MPP dihydrochloride and PHTPP (antagonists for the receptors $E R \alpha$ and $E R \beta$, respectively), suggesting that this is, at least partially, the mechanism of action of the neurogenic effects of the flavonoid. In these same cultures, when subjected to glutamate-induced excitotoxicity (an important cause of neurodegeneration in several pathologies such as Alzheimer's and Parkinson's diseases), treatment with agathisflavone at $10 \mu \mathrm{M}$ significantly reduced glutamate-induced cell death, in addition to reducing the expression of pro-cytokine inflammatory agents (including TNF, IL1 $\beta$ and IL6) associated with neurotoxicity. It was also able to increase the expression of IL-10 cytokine and arginase-1 enzyme, which are associated with anti-inflammatory and neuroprotective microglia. The authors also observed that the flavonoid induced increased expression of neuroprotective trophic factors such as brain-derived neurotrophic factor (BDNF), nerve growth factor (NGF), neurotrophin-4 (NT4) and glial cell line-derived neurotrophic factor (GDNF). The neuroprotective effects of agathisflavone against glutamate-induced excitotoxicity have been associated with the increased expression of glutamate regulatory proteins in astrocytes, glutamine synthetase (GS) and excitatory amino acid transporter 1 (EAAT1).

\section{Other pharmacological effects}

The first and only in vivo test using agathisflavone reported in the literature was made by Anand et al. (1992) (25) and published under the title "Structure and hepatoprotective activity of a biflavonoid from Canarium manii" in the journal Planta Medica. In this study, the authors report that in Charles-Foster rats and Swiss albino mice undergoing carbon tetrachloride-induced hepatic injury, agathisflavone given orally (50 mg and $100 \mathrm{mg}$ ) one hour before the injury provided dose-dependent hepatoprotective effects, decreasing serum levels of aspartate aminotransferase and alanine aminotransferase in animals compared to the untreated group, suggesting that the flavonoid contributed to preserve hepatocyte integrity.

De Souza et al. (2015b) (14) published the only report found in the literature on the antiprotozoal effect of the flavonoid agathisflavone. L-cathepsin rCPB2.8 is present in Leishmania mexicana (one of the parasites that cause leishmaniasis) and is an important protease for the suppression of the immune response of infected individuals and is, therefore, a promising molecular target in the therapy against this protozoan. Agathisflavone was able to partially and non-competitively inhibit the enzyme rCPB2.8 with an EC50 of $0.43 \pm 0.04 \mu \mathrm{M}$ and $\mathrm{Ki}$ values of $0.14 \pm 0.04 \mu \mathrm{M}$.

Agathisflavone extracted from the plant Ouratea polyantha Engl. (Ocnhaceae) demonstrated in vitro at a concentration of $2.5 \mathrm{ppm}$ the ability to inhibit the glucose-6-phosphatase enzyme present in murine hepatocytes, which is a potential target for the treatment of diabetes (29). Campana et al. (2015) (44) tested the ability of several flavonoids extracted from Ouratea semiserrata to decrease the release of TNF- $\alpha$ by monocytic THP- 1 cells activated by LPS. Agathisflavone did not demonstrate antiinflammatory effects in this study at any of the concentrations adopted but showed cytotoxicity at concentrations greater than $62.5 \mu \mathrm{M}$. 


\section{CONCLUSIONS}

Based on this prospective study, 81 publications were identified on the PubMed and Science Direct databases from the key descriptor agathisflavone and, although the flavonoid has been known in the literature since at least 1969, only 23 of the articles found evaluated its possible therapeutic effects. The research also revealed an increase in the number of publications mentioning agathisflavone over the last decade, indicating a possible increased interest in the flavonoid. The demonstrated biological activities of agathisflavone range from antiprotozoal to neurogenesis and neuroprotection. However, with one exception, the molecule has only been tested in vitro and needs to be better studied at the in vivo and human level.

Table 1. Biological activities of the flavonoid agathisflavone found on the PubMed and Science Direct databases.

\begin{tabular}{|c|c|c|}
\hline Biological activity & Origin & Authors \\
\hline $\begin{array}{l}\text { Antibiotic } \\
\text { B. subtilis NCIB } 3610 \\
\text { C. sporogenes NCIB } 532 \\
\text { E. coli ATCC } 25922 \\
\text { K. pneumonia (clinical) } \\
\text { P. fluorescence NCIB } 3756 \\
\text { P. aeruginosa ATCC } 27853 \\
\text { S. aureus ATCC } 29213\end{array}$ & Anacardium occidentale $L$. & Ajileye et al., 2015 \\
\hline $\begin{array}{l}\text { Antiviral } \\
\text { HIV-1 } \\
\text { Influenza A (H1N1) } \\
\text { Influenza B } \\
\text { Dengue (sorotype 2) }\end{array}$ & $\begin{array}{l}\text { Searsia succedanea (Rhus } \\
\text { succedanea); Cenostigma } \\
\text { macrophyllum }\end{array}$ & Lin et al. 1997 and 1999; De Sousa et al, 2015 \\
\hline $\begin{array}{l}\text { Antiprotozoal } \\
\text { Leishmania mexicana }\end{array}$ & Cenostigma macrophyllum & De Sousa et al, 2015 \\
\hline Hepatoprotective & Canarium manii & Anand et al, 1992 \\
\hline Antitumor & Anacardium occidentale $L$. & $\begin{array}{l}\text { Konan et al., 2012; Ndongo et al, 2015; } \\
\text { Taiwo et al, } 2017\end{array}$ \\
\hline Antidiabetic & $\begin{array}{l}\text { Ouratea polyantha Engl. } \\
\text { (Ocnhaceae) }\end{array}$ & Bermudez et al, 2012 \\
\hline \multicolumn{3}{|l|}{ Effects on the nervous system } \\
\hline Anti-inflammatory (microglia) & $\begin{array}{l}\text { Caesalpinia pyramidalis } \\
\text { (Poincianella pyramidalis) }\end{array}$ & Dos Santos Souza et al, 2018 \\
\hline Neuroprotective & $\begin{array}{l}\text { Caesalpinia pyramidalis } \\
\text { (Poincianella pyramidalis) }\end{array}$ & Dos Santos Souza et al, 2018 \\
\hline Neurogenic & $\begin{array}{l}\text { Caesalpinia pyramidalis } \\
\text { (Poincianella pyramidalis) }\end{array}$ & $\begin{array}{l}\text { Paulsen et al., 2011; Dos Santos Souza et al, } \\
2018\end{array}$ \\
\hline Affinity for $\mathrm{GABA}_{\mathrm{A}}$ receptor & $\begin{array}{l}\text { Searsia pyroides (Rhus } \\
\text { pyroides); Searsia dentata } \\
\text { (Rhus dentata); Searsia } \\
\text { pentheri (Rhus pentheri; } \\
\text { Searsia parviflora (Rhus } \\
\text { parviflora) }\end{array}$ & Svenningsen et al. 2006; Shresta et al, 2012 \\
\hline \multirow{2}{*}{$\begin{array}{l}\text { Enhanced expression of glutamate } \\
\text { transporters } \\
\text { Enhanced expression of retinoic } \\
\text { acid receptors }\end{array}$} & $\begin{array}{l}\text { Caesalpinia pyramidalis } \\
\text { (Poincianella pyramidalis) }\end{array}$ & Dos Santos Souza et al, 2018 \\
\hline & $\begin{array}{l}\text { Caesalpinia pyramidalis } \\
\text { (Poincianella pyramidalis) }\end{array}$ & Paulsen et al., 2011 \\
\hline
\end{tabular}




\section{ACKNOWLEDGMENTS}

We thank the following funding agencies: the Bahia State Research Support Foundation (FAPESB), the Higher Education Personnel Improvement Coordination (CAPES) and the National Research Council (CNPq), and the Post-graduation Program of Animal Science in the Tropics of the Federal University of Bahia.

\section{REFERENCES}

1. Falcone Ferreyra, M. L., Rius, S. P. and Casati, P. (2012) 'Flavonoids: biosynthesis, biological functions, and biotechnological applications', Frontiers in Plant Science, 3(September), pp. 1-15. doi: 10.3389/fpls.2012.00222.

2. Ávalos, A. and Elena, G. (2009) 'Metabolismo secundario de plantas', Reduca Biología Serie Fisiología Vegetal, 2(3), pp. 119-145. Available at: http://revistareduca.es/index.php/biologia/article/vie wFile/798/814.

3. Coelho, P. L. C. et al. (2016) 'Flavonoids from the Brazilian plant Croton betulaster inhibit the growth of human glioblastoma cells and induce apoptosis', Revista Brasileira de Farmacognosia. Sociedade Brasileira de Farmacognosia, 26(1), pp. 34-43. doi: 10.1016/j.bjp.2015.05.013.

4. Xiao, C.-J. et al. (2014) 'Schistosomicidal and Antioxidant Flavonoids from Astragalus englerianus', Planta Medica, 80(18), pp. 1727-1731. doi: 10.1055/s-0034-1383219.

5. Hossain, M. K. et al. (2014) 'Antiviral activity of 3,4'-dihydroxyflavone on influenza a virus', Journal of Microbiology, 52(6), pp. 521-526. doi: 10.1007/s12275-014-4212-z.

6. Hariri, B. M. et al. (2017) 'Flavones modulate respiratory epithelial innate immunity: Antiinflammatory effects and activation of the T2R14 receptor', Journal of Biological Chemistry, 292(20), pp. 8484-8497. doi: 10.1074/jbc.M1 16.771949.

7. Thapa, A. et al. (2011) 'Biflavonoids Are Superior to Monoflavonoids in Inhibiting Amyloid- $\beta$ Toxicity and Fibrillogenesis via Accumulation of Nontoxic Oligomer-like Structures', Biochemistry, 50(13), pp. 2445-2455. doi: 10.1021/bi101731d.

8. Sasaki, H. et al. (2015) 'Inhibitory activities of biflavonoids against amyloid- $\beta$ peptide 42 cytotoxicity in PC-12 cells', Bioorganic \& Medicinal Chemistry Letters. Elsevier Ltd, 25(14), pp. 28312833. doi: 10.1016/j.bmcl.2015.04.106.

9. Osorio, E., Londoño, J. and Bastida, J. (2013) 'LowDensity Lipoprotein (LDL)-Antioxidant Biflavonoids from Garcinia madruno', Molecules, 18(5), pp. 6092-6100. doi: 10.3390/molecules 18056092 .
10. Bahia, M. V. et al. (2005) 'Biflavonoids and other phenolics from Caesalpinia pyramidalis (Fabaceae)', Journal of the Brazilian Chemical Society, 16(6b), pp. 1402-1405. doi: 10.1590/S010350532005000800017.

11. Ajileye, O. O. et al. (2015) 'Isolation and characterization of antioxidant and antimicrobial compounds from Anacardium occidentale L. (Anacardiaceae) leaf extract', Journal of King Saud University - Science. King Saud University, 27(3), pp. 244-252. doi: 10.1016/j.jksus.2014.12.004.

12. Lin, Y.-M. et al. (1997) 'In Vitro Anti-HIV Activity of Biflavonoids Isolated from Rhus succedanea and Garcinia multiflora', Journal of Natural Products, 60(9), pp. 884-888. doi: 10.1021/np9700275.

13. de Sousa, L. R. F. et al. (2015) 'Natural products as inhibitors of recombinant cathepsin L of Leishmania mexicana', Experimental Parasitology. Elsevier Inc., 156, pp. 42-48. doi: 10.1016/j.exppara.2015.05.016.

14. de Sousa, L. R. F. et al. (2015) 'Flavonoids as noncompetitive inhibitors of Dengue virus NS2BNS3 protease: Inhibition kinetics and docking studies', Bioorganic \& Medicinal Chemistry. Elsevier Ltd, 23(3), pp. 466-470. doi: 10.1016/j.bmc.2014.12.015.

15. Konan, N. A. et al. (2012) 'Cytotoxicity of cashew flavonoids towards malignant cell lines', Experimental and Toxicologic Pathology. Elsevier GmbH., 64(5), pp. 435-440. doi: 10.1016/j.etp.2010.10.010.

16. Taiwo, B. J. et al. (2017) 'Identification of compounds with cytotoxic activity from the leaf of the Nigerian medicinal plant, Anacardium occidentale L. (Anacardiaceae)', Bioorganic \& Medicinal Chemistry. Elsevier Ltd, 25(8), pp. 23272335. doi: 10.1016/j.bmc.2017.02.040.

17. Paulsen, B. S. et al. (2011) 'Agathisflavone Enhances Retinoic Acid-Induced Neurogenesis and Its Receptors $\alpha$ and $\beta$ in Pluripotent Stem Cells', Stem Cells and Development, 20(10), pp. 1711-1721. doi: 10.1089/scd.2010.0446.

18. dos Santos Souza, C. et al. (2018) 'Agathisflavone, a flavonoid derived from Poincianella pyramidalis (Tul.), enhances neuronal population and protects against glutamate excitotoxicity', NeuroToxicology. Elsevier B.V., 65, pp. 85-97. doi: 10.1016/j.neuro.2018.02.001.

19. Pelter, A. et al. (1969) 'The isolation and characterization of two members of a new series of naturally occurring biflavones', Experientia, 25(4), pp. 351-352. doi: 10.1007/BF01899909.

20. Chexal, K. K., Handa, B. K. and Rahman, W. (1970) 'Thin-layer chromatography of biflavonyls on silica gel', Journal of Chromatography A, 48, pp. 484-492. doi: 10.1016/S0021-9673(01)85582-5.

21. Yuh-Meei, L. and Fa-Ching, C. (1974) 'Agathisflavone from the drues of Rhus succedanea', 
Phytochemistry, 13(3), pp. 657-658. doi: 10.1016/S0031-9422(00)91375-X.

22. Ilyas, N. et al. (1978) 'Biflavones from the leaves of Araucaria excelsa', Phytochemistry, 17(5), pp. 987990. doi: 10.1016/S0031-9422(00)88662-8.

23. Wannan, B. S. et al. (1985) 'Biflavonyls and the affinities of Blepharocarya', Biochemical Systematics and Ecology, 13(2), pp. 105-108. doi: 10.1016/03051978(85)90066-3.

24. Wannan, B. S. and Quinn, C. J. (1988) 'Biflavonoids in the julianiaceae', Phytochemistry, 27(10), pp. 3161-3162. doi: 10.1016/0031-9422(88)80019-0.

25. Anand, K. K. et al. (1992) 'Structure and hepatoprotective activity of a biflavonoid from Canarium manii.', Planta medica, 58(6), pp. 493495. doi: 10.1055/s-2006-961533.

26. Mendes, C. C. et al. (2000) 'Constituents of Caesalpinia pyramidalis', Fitoterapia, 71(2), pp. 205-207. doi: 10.1016/S0367-326X(99)00145-8.

27. Pegnyemb, D. E. et al. (2005) 'Antimicrobial biflavonoids from the aerial parts of Ouratea sulcata', Phytochemistry, 66(16), pp. 1922-1926. doi: 10.1016/j.phytochem.2005.06.017.

28. Svenningsen, A. B. et al. (2006) 'Biflavones from Rhus species with affinity for the GABAA/benzodiazepine receptor', Journal of Ethnopharmacology, 103(2), pp. 276-280. doi: 10.1016/j.jep.2005.08.012.

29. Bermúdez, J. et al. (2012) '(6R,9S)-6"-(4"hydroxybenzoyl)-roseoside, a new megastigmane derivative from Ouratea polyantha and its effect on hepatic glucose-6-phosphatase.', Natural product communications, 7(8), pp. 973-6. doi: 10.1002/nbm.3066.Non-invasive.

30. Bayiha Ba Njock, G. et al. (2012) 'NASCA-HMBC, a New NMR Methodology for the Resolution of Severely Overlapping Signals: Application to the Study of Agathisflavone', Phytochemical Analysis, 23(2), pp. 126-130. doi: 10.1002/pca.1333.

31. Feuereisen, M. M. et al. (2014) 'Characterization of Phenolic Compounds in Brazilian Pepper (Schinus terebinthifolius Raddi) Exocarp', Journal of Agricultural and Food Chemistry, 62(26), pp. 62196226. doi: 10.1021/jf500977d.

32. Ndongo, J. T. et al. (2015) 'Cytotoxic flavonoids and other constituents from the stem bark of Ochna schweinfurthiana', Natural Product Research, 29(17), pp. 1684-1687. doi: 10.1080/14786419.2014.991321.

33. Covington, C. L. et al. (2016) 'Atropoisomerism in Biflavones: The absolute configuration of (-)agathisflavone via chiroptical spectroscopy', Journal of Natural Products, 79(10), pp. 2530-2537. doi: 10.1021/acs.jnatprod.6b00395.

34. Lin, Y.-M., Chen, F.-C. and Lee, K.-H. (1989) 'Hinokiflavone, a Cytotoxic Principle from Rhus succedanea and the Cytotoxicity of the Related
Biflavonoids 1', Planta Medica, 55(02), pp. 166-168. doi: 10.1055/s-2006-961914.

35. Grynberg, N. F. et al. (2002) 'DNA topoisomerase inhibitors: biflavonoids from Ouratea species.', Brazilian journal of medical and biological research $=$ Revista brasileira de pesquisas medicas e biologicas, 35(7), pp. 819-22. Available at: http://www.ncbi.nlm.nih.gov/pubmed/12131922.

36. Marzouk, M. M. (2016) 'Flavonoid constituents and cytotoxic activity of Erucaria hispanica (L.) Druce growing wild in Egypt', Arabian Journal of Chemistry. King Saud University, 9, pp. S411-S415. doi: 10.1016/j.arabjc.2011.05.010.

37. Lin, Y.-M. et al. (1999) 'Antiviral Activities of Biflavonoids', Planta Medica, 65(2), pp. 120-125. doi: 10.1055/s-1999-13971.

38. Zembower, D. E. et al. (1998) 'Robustaflavone, a potential non-nucleoside anti-hepatitis B agent', Antiviral Research, 39(2), pp. 81-88. doi: 10.1016/S0166-3542(98)00033-3

39. Lin, Y.-M. et al. (2001) 'Biflavonoids as novel antituberculosis agents', Bioorganic \& Medicinal Chemistry Letters, 11(16), pp. 2101-2104. doi: 10.1016/S0960-894X(01)00382-1.

40. Ngo Mbing, J. et al. (2006) 'Two biflavonoids from Ouratea nigroviolacea', Phytochemistry, 67(24), pp. 2666-2670. doi: 10.1016/j.phytochem.2006.07.027.

41. da Silva, J. H. S. et al. (2018) 'Anti- Escherichia coli activity of extracts from Schinus terebinthifolius fruits and leaves', Natural Product Research, 32(11), pp. 1365-1368. doi: 10.1080/14786419.2017.1344657.

42. Shrestha, S. et al. (2012) 'Rhus parviflora and its biflavonoid constituent, rhusflavone, induce sleep through the positive allosteric modulation of GABAA-benzodiazepine receptors', Journal of Ethnopharmacology. Elsevier, 142(1), pp. 213-220. doi: 10.1016/j.jep.2012.04.047.

43. Pedersen, M. E. et al. (2008) 'The effect of extracts of Searsia species on epileptiform activity in slices of the mouse cerebral cortex', Journal of Ethnopharmacology, 119(3), pp. 538-541. doi: 10.1016/j.jep.2008.08.009.

44. Campana, P. R. V et al. (2015) 'Anti-TNF- $\alpha$ Activity of Brazilian Medicinal Plants and Compounds from Ouratea semiserrata', Phytotherapy Research, 29(10), pp. 1509-1515. doi: 10.1002/ptr.5401. 